\title{
Sistem Pemilihan Raja Negeri Munarten Kecamatan Taniwel Kabupaten Seram Bagian Barat
}

\author{
Maria A. V. Touwe ${ }^{1}$ \\ Wahab Tuanaya ${ }^{2}$ \\ Marno Wance ${ }^{3}$ \\ Mahasiswa Ilmu Pemerintahan, Universitas Pattimura ${ }^{1}$ \\ Dosen Ilmu Pemerintahan, Universitas Pattimura ${ }^{23}$ \\ ipmummu@gmail.com

Keyword:
King Election;
Customary Provisions;
Domestic Democracy. \\ Kata Kunci: \\ Pemilihan Raja; \\ Ketentuan Adat; \\ Demokrasi Negeri.

\begin{abstract}
This research was conducted in Murnaten State with a research problem, namely Adat and Democracy (a study on the Election of the King) with the aim of researching how to apply customary provisions in the democratic era related to the Election of Kings in Murnaten State, Taniwel District, West Seram Regency. The results of this study indicate that (1) there is a mutual agreement on the implementation of the customary provisions, but now it is divided. (2) Initially, the government and the community were consistent in applying the customary provisions in the election of a king. (3) community support for the current customary provisions has been divided as a result of differences of opinion. (4) the community's obedience to all customary decisions has changed due to political interests. Therefore, it is concluded that currently, the government and the people of Negeri Murnaten are not in line in implementing the customary provisions related to the King Election process.
\end{abstract}

\begin{abstract}
Abstrak: Penelitian ini dilakukan di Negeri Murnaten dengan masalah penelitian yaitu Adat Dan Demokrasi (studi tentang Pemilihan Raja) dengan tujuan penelitian bagaimana penerapan ketentuan adat dalam era demokrasi terkait Pemilihan Raja di Negeri Murnaten, Kecematan Taniwel, Kabupaten Seram Bagian Barat. Hasil penelitian ini menunjukan bahwa (1) sudah ada kesepakaan bersama terhadap pemberlakuan ketentuan adat akan tetapi sekarang sudah terbagi. (2) pada awalnya pemerintah dan masyarakat konsisten dalam menerapkan ketentuan adat dalam pemilihan raja namun, saat ini masyarakat mengalami perubahan pemikiran dalam hal ketentuan adat mengenai pemilihan raja. (3) dukungan masyarakat terhadap ketentuan adat saat ini telah terbagi akibat dari perbedaan pendapat. (4) ketaatan masyarakat terhadap seluruh keputusan adat mengalami perubahan akibat dari kepentingan politik. Oleh karena itu disimpulkan bahwa saat ini antara pemerintah dan masyarakat Negeri Murnaten tidak sejalan dalam menerapkan ketentuan-ketentuan adat terkait proses Pemilihan Raja.
\end{abstract}

\section{PENDAHULUAN}

Negara mengakui dan menghormati kesatuan masyarakat hukum adat beserta hak tradisionalnya sepanjang masih hidup dan sesuai dengan perkembangan masyarakat dan prinsip Negara kesatuan republik Indonesia (NKRI). Sistem Pemerintahan Desa di Maluku, di kenal dengan pemerintah negeri dan umumnya berlaku di pulau Ambon dan di seluruh Kabupaten/kota termasuk halnya pada Kabupaten Seram Bagian Barat. Pemerintah Negeri adalah merupakan basis masyarakat adat dan memiliki batas-batas wilayah darat dan laut yang jelas di sebut petuanan negeri. Undang-Undang Nomor 32 Tahun 2004 Tentang Pemerintahan Daerah dan Peraturan Pemerintah Nomor 72 Tahun 2005 Tentang Desa, menetapkan Desa atau yang disebut dengan nama tertentu merupakan kesatuan masyarakat hukum yang memiliki batas wilayah, berwenang untuk mengatur dan mengurus kepentingan masyarakat setempat 
berdasarkan asal-usul dan adat istiadat setempat yang diakui dan dihormati dalam sistem Pemerintahan Negara Kesatuan Republik Indonesia dan berada di Kabupaten/Kota.

Landasan pemikiran tentang pengaturan mengenai desa yaitu keanekaragaman, partisipasi, otonomi asli, demokrasi dan pemberdayaan masyarakat. Untuk menjabarkan lebih jauh jiwa dan semangat yang terkandung dalam Pasal 18B UUD 1945 dan Undang-Undang Nomor 32 Tahun 2004, maka Pemerintah Daerah Provinsi Maluku menerbitkan Peraturan Daerah yang merupakan ketentuan payung (umbrella Provision) untuk melahirkan berbagai kebijakan regulasi pada tataran tata hukum lokal yang diharapkan mampu menjadikan wilayah Kabupaten Seram Bagian Barat, Kecamatan Taniwel, Desa Murnaten berkembang lebih maju sesuai dengan ciri dan karakaterisitik daerahnya. Peraturan Daerah yang dimaksud adalah Peraturan Daerah Provinsi Maluku Nomor 14 Tahun 2005 Tentang Penetapan Kembali Negeri Sebagai Kesatuan Masyarakat Hukum Adat Dalam Wilayah Pemerintahan Provinsi Maluku yang pada prinsipnya menetapkan negeri sebagai kesatuan masyarakat hukum adat di Provinsi Maluku. Masyarakat Kabupaten Seram Bagian Barat pada umumnya merupakan masyarakat adat, dikenal kesatuan masyarakat hukum adat dengan nama Negeri yang diatur berdasarkan hukum adat setempat, kesatuan-kesatuan masyarakat adat tersebut beserta perangkat pemerintahannya telah lama ada, hidup dan berkembang serta dipertahankan dalam tata pergaulan hidup masyarakat. Negeri di Kabupaten Seram Bagian Barat sebagai kesatuan masyarakat hukum adat, memiliki kewenangan untuk mengatur dan mengurus kepentingan masyarakat setempat berdasarkan hak, asal-usul Negeri, adat istiadat dan hukum adat yang diakui dalam Sistem Pemerintahan Nasional.

Negeri/Negeri Administratif menempatkan adat istiadat dan hukum adat dalam konteks yang susungguhnya. Oleh karena itu otonomi Negeri sebagai otonomi bawaan dan otonomi Negeri Administrati sebagai otonomi yang diberikan, hendaknya dikembangkan untuk kepentingan masyarakat Negeri/Negeri Administratif yang tidak terlepas dari kendali Pemerintah (Pemerintah Provinsi Maluku dan Kabupaten Seram Bagian Barat) sepanjang menyangkut kepentingan Nasional yang harus dilaksanakan. Dalam rangka kelancaran penyelenggaraan pemerintahan, pembangunan, demokrasi dan kemasyarakatan Negeri maka adanya Pemerintah Negeri menjadi faktor penting. Untuk itu Pemerintah Daerah Kabupaten Seram Bagian Barat belum memiliki peraturan sendiri mengenai pencalonan, pemilihan dan pelantikan Raja sehingga pemerintah Kabupaten Seram Bagian Barat masih menggunakan Perbup No 04 tahun 2016 Tentang Tata Cara Pencalonan, Pemilihan, Pelantikan Raja.

Mekanisme atau sistem dalam pencalonan, pemilihan dan pelantikan Kepala Pemerintah Negeri yang merupakan tuntutan prinsip demokrasi dan harus ditopang dengan sistem hukum, yang dapat dijadikan sebagai acuan, sehingga dapat melahirkan figur pemimpin dengan tetap menghargaih ak-hak anggota masyarakat, sebagai bagian dari hak asasi manusia. Sistem demokrasi yang dibangun tetap memperhatikan sistem pemerintahan pada umumnya, yang akan melahirkan seorang pemimpin pada Kesatuan Masyarakat Adat dengan tidak mengabaikan prinsip-prinsip hukum adat maupun peraturan perundang-undangan yang berlaku. Masyarakat adat di Kabupaten Seram Bagian Barat, Kecamatan Taniwel, Negeri Murnaten sebagian besar masih menghargai figur seorang pemimpin pada Kesatuan Masyarakat Hukum Adat yang berasal dari turunan matarumah/keturunan yang menurut hukum adat Kabupaten Seram Bagian Barat berhak menyandang gelar dan kharisma pemimpin tersebut dan tidak dapat dialihkan kepada pihak luar, kecuali dalam hal-hal khusus yang ditetapkan berdasarkan hasil musyawarah matarumah/keturunan yang berhak bersama Saniri Negeri.

Negeri Murnaten adalah salah satu negeri/desa adat di Kecamatan Taniwel yang mekenisme penyelenggaraan pemerintahannya berdasarkan hak asal-usul dan adat istiadat negeri setempat. Sejalan dengan itu pola penyelenggaraan pemerintahan pada tingkat negeri di Kecamatan Taniwel mempunyai kerakteristik tersendiri, dimana sebagian besar wilayah masyarakat hukum berstatus negeri dengan sistem pemerintahan adat yang berlaku secara turun-temurun dan hidup, dihormati serta dipertahankan. Hal tersebut kemudian diperkuat dengan ditetapkannya peraturan daerah kota ambon nomor 3 tahun 2008 tentang negeri. Peraturan daerah nomor 18 tahun 2007, tentang pedoman umum, pembinaan, pengawasan penyelenggaraan pemerintah negeri. Peraturan daerah (perda) terkait negeri adat di Negeri 
Murnaten tersebut menimbulkan implikasi bagi sistem pemilihan atau pengangkatan kepela pemerintahan negeri adat di negeri-negeri kecamatan taniwel.

Peraturan daerah No 3 tahun 2008 tentang negeri pasal 19 ayat (2) disebutkan bahwa; pengisian jabatan raja dapat dilakukan melalui pemilihan dan/atau pengangkatan. Pasal 2 ayat (1) perda nomor 13 tahun 2008 juga mengaturnya bahwa penetapan raja dilakukan melalui pengangkatan dan pemilihan. Sedangkan pasal 18 ayat (1) menerangkan bahwa raja diutamakan berasal dari anak negeri atau anak adat dari mata rumah soa parentah. Selanjutnya pada ayat (2), apabila ketentuan tersebut (pada ayat 1) tidak dapat dipenuhi maka dapat diusulkan anak negeri dari soa, yang mekanisme pengusulannya dengan terlebih dahulu melakukan musyawarah soa parentah (pasal 18 ayat 3). Pada bagian lain perda nomor 13 tahun 2008 pasal 2 ayat (2) juga menyebutkan secara khusus tentang pengangkatan raja bahwa, pengangkatan raja dilakukan apabila calon diajukan untuk menjadi raja hanya satu orang, selanjutnya pada pasal 2 ayat (3) ditegaskan kembali bahwa, pemilihan raja dilakukan apabila calon yang diajukan untuk menjadi raja lebih dari satu orang calon yang berasal dari soa parentah yang berhak menjadi raja tersebut.

Adapun mekanisme pengusulan pancalonan raja diajukan oleh soa parentah kepada saniri negeri. Disamping itu, jika salah satu soa parentah tidak mengusulkan calonnya maka, soa parentah tersebut dapat memberikan rekomendasi kepada soa lain diluar soa parentah. Adapun terkait mekanisme pemilihan Raja di Negeri Murnaten dimana memiliki beberapa kendala, salah satunya adalah pertentangan/selisih pendapat antara pemuda dan tetua adat mengenai pengangkatan/pemilihan Raja. Dimana para pemuda menginginkan pemilihan Raja atau pengangkatan Raja sesuai dengan Sistem Demokrasi bukan lagi secara Adat. Sedangkan tetua adat menginginkan pemilihan Raja atau pengangkatan Raja harus sesuai dengan sistem Adat yang berlaku secara turun-temurun yang ada di Negeri Murnaten, sehingga dari selisih pendapat dari pemuda dan tetua adat ini, terjadi kekacauan pada saat pelantikan raja yang dilakukan oleh pemuda dan berujung pada konflik internal yang berkepanjangan. Atas dasar itu, akahirnya menarik perhatian penulis untuk melakukan penelitian dengan judul Implementasi Ketentuan Adat di Era Demokrasi (Studi tentang pemilihan Raja di desa Murlaten Kecamatan Taniwel Kabupaten Seram Bagian Barat).

\section{Konsep Demokrasi Di Desa}

AAGN Ari Dwipayana dan Sutoro Eko (2003:21), mengungkapkan bahwa: "Pemerintahan demokratis (democratic governance), yaitu pemerintahan desa yang berasal dari (partisipasi) masyarakat, dikelola "oleh" (akuntabilitas dan transparasi) masyarakat dan dimanfaatkan sebaik-baiknya "untuk" (responsivitas) masyarakat." Demokrasi di Desa dapat dilihat dari keterlibatan atau partisipasi masyarakat dalam pengelolaan pemerintahan dan pembangunan di desa untuk mencapai kebaikan bersama secara kolektif. Desa adalah kesatuan masyarakat hukum yang memiliki batas-batas wilayah yurisdiksi, yang berwenang untuk mengatur dan mengurus kepentingan masyarakat setempat berdasarkan asal-usul dan adat istiadat setempat yang diakui dan atau dibentuk dalam sistem Pemerintahan Nasional dan berada di Kabupaten/Kota. Desa yang dimaksud dalam ketentuan Undang-Undang Nomor 32 Tahun 2004, dalam penjelasnnya yaitu antara lain Nagari di Sumatera Barat, Gampong di Provinsi NAD, Lembang di Sulawesi Selatan, Kampung di Kalimatan Selatan dan Papua serta Negeri di Maluku. Desa adalah suatu kesatuan hukum dimana bertempat tinggal suatu masyarakat yang berkuasa untuk melaksanakan pemerintahan sendiri. 
Sedangkan persyaratan terbentuknya desa terdiri dari lima syarat menurut HAW. Widjaja (2000:46) yaitu :

1. Jumlah penduduk minimal 150 atau 300 Kepala Keluarga (KK)

2. Luas Wilayah

3. Sosial Budaya

4. Potensi Desa

5. Sarana dan Prasarana

\section{Sistem Pemerintahan Negeri}

Sistem pemerintahan Negeri di Maluku pada rezim adat di kenal dengan Pemerintah Negeri dan berlaku di Pulau Ambon dan Kabupaten Seram Bagian Barat. Pemerintah Negeri adalah merupakan basis masyarakat adat dan memiliki batas-batas wilayah darat dan laut yang jelas disebut petuanan negeri, dan sistem pemerintahan yang bersifat geneologis atau berdasarkan garis keturunan. Pada rezim adat, setiap Negeri memiliki struktur organisasi pemerintahan negeri. Susunan pemerintahan negeri adalah warisan dari pemerintahan Belanda dimana sistem hukum adat ini ditetapkan dalam keputusan Landraad Amboina No.14 Tahun 1919; disebutkan bahwa Pemerintah Negeri adalah regent en de kepala soas's. Selanjutnya didalam keputusan landraad Amboina No.30 Tahun 1919 disebutkan bahwa negorij bestuur adalah regent en de Kepala-Kepala Soa, yang berarti bahwa pelaksanaan pemerintahan negeri dilaksanakan oleh Raja dan Kepala-kepala Soa. Di samping Saniri Rajapati ada Saniri Negeri yang merupakan kumpulan wakil-wakil soa yaitu suatu kelompok masyarakt yang terdiri dari beberapa marga atau "mata rumah" (adat) yang memilih dan mengangkat salah satu anggotanya sebagai wakil pada Saniri Negeri dan 1 orang sebagai Kepala Soa. Di dalam pelaksanaan pemerintahan negeri, maka dikenal ada badan legislatif yang dikenal dengan sebutan Saniri Negeri Lengkap.

Saniri Negeri Lengkap terdiri dari: anggota Saniri, para tua-tua adat dan tokoh-tokoh masyarakat yang berpengaruh seperti guru, pegawai, tokoh agama (pendeta/imam), Kewang; penjaga keamanan desa dan pengawas hutan dan laut, Kapitan; pemimpin perang, Marinyo; orang yang bertanggung jawab untuk mengkomunikasikan keputusan pemerintah (Raja) kepada staf pemerintah negeri maupun kepada masyarakat, Tuan Negeri; sebagai pemimpin pelaksana adat dalam negeri, dan Tuan Tanah. Tugas Saniri Negeri Lengkap adalah menentukan kebijaksanaan dan mengeluarkan peraturan-peraturan bersama dengan Saniri Raja Patti dalam melaksanakan sesuatu hal yang penting di negeri akan berkonsultasi terlebih dahulu dengan Saniri Negeri Lengkap untuk meminta persetujuannya. Pimpinan Saniri Negeri Lengkap ini adalah Raja, namun selain bertugas sebagai badan legislatif maka Saniri Negeri Lengkap juga bertugas untuk memilih Raja menurut tata cara yang berlaku. Penelitian yang dilakukan oleh Waance, dkk (2020) Penerapan system kerajaan atau kepala pemerintah di pimpin oleh Bapak Raja sudah terjadi sejak masa lampu dan tetap dilestarikan sebagai model pemerintahan di tingkat desa. Sedangkan lembaga BPD sebagai lembaga mitra perencanaan pemerintah desa serta lembaga yang mempunya fungsi pengawasan di sebut sebagai lembaga "Saniri" Negeri yang mempunyai tugas untuk menjaga nilai-nilai adat tetap dijaga dan dipertahankan dalam menjalankan pemerintahan desa di Negeri Hila, Kabupaten Maluku Tengah. (Wance, Muhtar, Kaliky, 2020).

Badan Musyawarah Negeri yang di kenal dengan sebutan Sandiri Negeri Besar yang peran sebagai badan yudikatif. Saniri Negeri Besar bertugas menyelengarakan rapat lengkap yang 
bersifat terbuka antara Saniri Raja Patti dan Saniri Negeri Lengkap dan semua warga masyarakat pria dewasa yang berumur 18 tahun keatas. Rapat ini dilaksanakan 1 tahun sekali biasanya diawal tahun atau pada akhir tahun dan berlangsung dirumah adat yang disebut Baeleo dan pimpinan oleh Raja. Seperti halnya di Negeri-negeri Adat lainnya di Maluku, peran Soa Parentah mempunyai andil besar dalam penentuan bakal calon Kepala Parentah Negeri yang berhak mengikuti pemilihan. Pengajuan bakal calon yang diajukan oleh Soa Parentah menjadi bukti bahwa peran Soa Parentah didalam penyelenggaraan pemilihan Kepala Pemerintah Negeri. Hal ini merupakan ketentuan hukum adat yang sudah berlaku sejak negeri itu ada. Seorang Kepala Pemerintahan Negeri (Raja) hampir dipastikan berasal dari garis keturunan Raja pula. Tradisi ini dimulai dari zaman colonial belanda, bahkan mungkin di jamanjaman sebelumnya. Pemilihan kepala pemerintah negeri, masyarakat umumnya masih mendukung calon dari keturunan keluarga Raja. Fenomena ini adalah karena faktor tradisi dan adat yang masih cukup dihormati oleh masyarakat.

\section{Konsep Negeri}

Konsep Negeri bukanlah berasal dari bahasa asli daerah Maluku atau "bahasa tanah", tetapi berasal dari Sumatera Barat, yaitu kata "nagari". Suatu negeri adalah persekutuan territorial, terdiri atas beberapa soa yang pada umumnya berjumlah paling sedikit tiga buah. Sebuah negeri dipimpin oleh seorang kepala negeri yang disebut pamarentah dan sehari-hari dipanggil "Raja". Sekarang ini susunan wilayah pemerintah negeri adalah wilayah yang membentuk negeri. Dibawahnya terdapat wilayah-wilayah soa yang terbentuk dari beberapa rumah tau sebagai persekutuan geneologis (punya pertalian darah). Negeri dikepalai oleh seorang raja yang bergelar Latu, Patty atau Kamar. Dalam tingkatannya Latu menempati posisi teratas, karena merupakan gelar adat asli masyarakat Maluku. Patty adalah gelar pemberian Belanda yang diambil dari gelar di jawa. Sedangkan gelar Kamar (orang kaya) diambil dari Sumatera (H. M. Saleh Putuhena, dkk. 2009: 57).

Pendapat lainnya juga menurut R. Bintarto dalam Hanif Nurcholis (2011: 4), Desa adalah suatu perwujudan geografis yang ditimbulkan oleh unsur-unsur fisiografis sosial ekonomis, politis dan kultural yang terdapat disitu dalam hubungan dan pengaruh timbal balik dengan daerah-daerah lain. Desa adalah suatu wilayah yang di diami oleh sejumlah penduduk yang saling mengenal atas dasar hubungan kekerabatan dan atau kepentingan politik, sosial, ekonomi, dan keamanan yang dalam pertumbuhannya menjadi kesatuan masyarakat hukum berdasarkan adat sehingga tercipta ikatan lahir batin antara masing-masing warganya, umumnya warganya hidup dari pertanian, mempunyai hak mengatur rumah tangga sendiri, dan secara administratif berada dibawah pemerintahan kabupaten/kota.

Dari pendapat-pendapat ahli di atas, menurut peneliti Desa atau Negeri merupakan suatu daerah atau wilayah yang dihuni oleh masyarakat yang hidup bersama serta memiliki satu kesatuan. Istilah umum yang di kenal untuk mengidentifikasi kelompok masyarakat yang mendiami suatu tempat di Maluku dengan nama yaitu Negeri. Walaupun kenyataannya keberadaan negeri dapat disamakan dengan desa di pulau Jawa. Dalam berbagai literature diketahui bahwa negeri bukanlah berasal dari bahasa asli daerah ini atau "bahasa tanah".

Menurut Cooley, Negeri adalah bentuk Melayu dari kata sansekerta nagara, yang berarti daerah, kota atau kerajaan (suatu wilayah pemerintahan). Hal ini dipertegas oleh Leirissa bahwa, sesungguhnya negeri merupakan ciptaan VOC dari awal abad ke-17. Negeri-negeri tercipta ketika terjadi peperangan untuk menguasai perdagangan cengkeh antara VOC dan Ternate di Maluku Tengah. Uli-uli yang berada di pengunungan yang cenderung melawan kekuasaan VOC dipaksakan turun ke pesisir pantai dan menetap ditempat-tempat yang 
ditentukan oleh VOC. Tempat-tempat baru ini diberi nama "negeri". Dalam dokumen-dokumen VOC disebut negorji. Negeri Maluku pada dasarnya memiliki adat serta kebudayaan yang merupakan hasil kerja dan cipta dari leluhur untuk dijadikan sebagai aturan atau norma yang terus di praktekan di dalam kehidupan bersama. Negeri adalah persekutuan territorial yang terdiri atas beberapa soa. Pada umumnya terdapat minimal tiga soa untuk sebuah negeri. Negeri dipimpin oleh kepalah negeri yang sehari-hari dipanggil "Raja". Dibawahnya terdapat wilayah soa yang terbentuk dari beberapa rumah atau sebagai persekutuan genealogis. Negerinegeri yang terdapat di Ambon dan sekitarnya masing-masing berdiri sendiri tidak merupakan suatu kesatuan. Karena itu kepadanya dijuluki Dorps repulieken dengan seorang pemimpin yang dipilih (pattiasina, 2012:54-56).

\section{Konsep Adat}

Syah (dalam Nurlina Ibrahim 2009:5) menjelaskan bahwa Adat adalah kaidah-kaidah sosial yang tradisional yang sakral ini berarti bahwa adat adalah ketentuan leluhur dan ditaati secara turun-temurun. Ia merupakan tradisi yang mengatur masyarakat penduduk asli Indonesia yang dirasakan oleh anggota-anggotanya sangat mengikat. Sebagai kaidah-kaidah sosial yang dianggap sakral, maka pelaksanaan adat ini hendaknya dilaksanakan berdasarkan norma-norma adat yang berlaku, disetiap daerah yang tanpa memperhatikan adanya stratifikasi dalam kehidupan masyarakat. Orang Minang terbiasa membedakan antara tiga kata : adat istiadat, adat nan diatakan, dan adat nan teradat, yang masing-masing mempunyai arti yang berbeda pula.

Menurut Soerjono Soekanto (1981 : 73) menjelaskan bahwa Adat Istiadat mempunyai ikatan dan pengaruh yang kuat dalam masyarakat. Kekuatan mengikatnya tergantung pada masyarakat (atau bagian masyarakat) yang mendukung adat istiadat tersebut yang terutama berpangkal tolak pada perasaan keadilannya. Menurut Soeripto (2009:5), Adat adalah semua aturan-aturan/peraturan-peraturan adat tingkah laku yang bersifat hukum di segala segi kehidupan orang indonesia, yang pada umumnya tidak tertulis yang oleh masyarakat di angggap patut dan mengikat para anggota masyarakat yang bersifat hukum oleh karena ada kesadaran keadilan umum, bahwa aturan-aturan/peraturan itu harus dipertahankan oleh para petugas hukum dan petugas masyarakat dengan upaya pemaksa atau ancaman hukum (sanksi).

Menurut Bushar Muhammad (2009:5), Adat adalah hukum yang mengatur tingkah laku manusia Indonesia dalam hubungan satu sama lain yang merupakan keseluruhan kelaziman, kebiasaan dan kesusilaan yang benar-benar hidup di masyarakat adat kerena dianut dan dipertahankan oleh anggota masyarakat itu, maupun yang merupakan keseluruhan peraturanperaturan yang mengenai sanksi atas pelanggaran yang ditetapkan dalam keputusan para penguasa adat (mereka yang mempunyai kewibawaan dan berkuasa memberi keputusan dalam masyarakat adat itu yaitu dalam keputusan lurah, penghulu, wali tanah, kepala adat dan hakim).

\section{Sistem Pemerintahan Adat}

Pembahasan Sistem Pemerintahan Desa Adat lebih mengacu pada System Pemerintahan Desa dengan prinsip-prinsip adat istiadat atau tradisional yang dianut oleh masyarakat tersebut secara turun-temurun. Menurut peraturan pemerintah nomor 75 tahun 2005 tentang Pemerintahan Desa adalah penyelenggaraan urusan pemerintahan oleh Pemerintah Desa dan Badan Permusyawaratan Desa (BPD) dalam mengatur dan mengurus kepentingan masyarakat setempat berdasarkan asal-usul, adat istiadat setempat yang diakui dan di hormati dalam System Pemerintahan Negara Kesatuan Republik Indonesia. Desa adalah Desa dan Desa Adat 
atau yang disebut dengan nama lain, selanjutnya disebut Desa adalah kesatuan masyarakat hukum yang memiliki wilayah yang berwenang untuk mengatur dan mengurus urusan pemerintahan, kepentingan masyarakat setempat berdasarkan prakarsa masyarakat, hak asalusul, dan atau hak tradisional yang diakui dan di hormati dalam System Pemerintahan Negara Kesatuan Republik Indonesia. Sejalan dengan itu, urusan Pemerintahan Desa mengatur kewenangan Desa meliputi bidang penyelenggaraan Pemerintahan Desa, pembinaan kemasyarakatan, dan pemberdayaan masyarakat Desa berdasarkan prakarsa masyarakat, hak asal-usul, dan adat istiadat Desa.

Selanjutnya pasal 19 Undang-undang nomor 6 tahun 2004 juga membagi kewenangan Desa dengan mempertimbangkan Sistem Pemerintahan Desa yakni:

1. Kewenangan berdasarkan hak asal-usul

2. Kewenangan lokal berskala desa

3. Kewenangan yang di tugaskan oleh pemerintah, pemerintah daerah provinsi, atau pemerintah daerah kabupaten/kota, dan

4. Kewenangan lain yang ditugaskan oleh pemerintah, pemerintah daerah provinsi, atau pemerintah daerah kabupaten/kota

Berangkat dari berbagai sistem penyelenggaraan Desa tersebut, maka objek implementasi tata pemerintahan di Desa Adat menggunakan Hukum Adat. Adapun System Pemerintahan Adat tidak saja berisi pemerintahan dalam arti sempit (bestuure), akan tetapi juga dalam arti luas (regeling), karena Desa berkuasa atas pengadilan, perundang-undangan, kepolisian dan pertahanan. Adapun tata Pemerintahan Desa Adat di seluruh Indonesia didasarkan dikenal dalam dua bentuk yaitu: 1) pimpinan pemerintahan diletakkan dalam tangan seorang, dan 2) pimpinan pemerintahan dipegang oleh sebuah dewan.

Menurut Margono Soeito, dalam sistem dan atau struktur pemerintahan adat di Maluku secara Umum yang antara lain sebagai berikut:

1. Raja

Raja sebagai kepala desa adat yang berfungsi sebagai kepala pemerintahan negeri yang dilindungi dan mengayomi warga masyarakat secara terpadu.

2. Aman

Aman Lembaga Adat sebagai Kepala Adat yang berfungsi sebagai pimpinan dalam pelaksanaan Upacara Adat dan memberikan bimbingan kepada masyarakat.

3. Kepala Soa

Kepala Soa sebagai bagian Negeri yang bertugas mengurusi Administrasi Pemerintahan Negeri sebagai sekertaris desa.

4. Marinyo

Marinyo sebagai penyiar yang bertugas menyampaikan berita bagi masyarakat negeri dan keluar negeri atau tetangga negeri.

5. Tuan Tanah

Tuan Tanah sebagai penyubur tanah pekerangan masyarakat dan sebagai orang yang ahlih dalam masalah dan sekaligus sebagai pemilik tanah yang luas di desa adat tersebut.

6. $\quad$ Kewang

Kewang sebagai polisi hutan yang bertugas menjaga kelestarian akan sumber daya yang terdapat dalam hutan dan bertanggung jawab sebagai jagawana.

7. Kapitan 
Kapitan sebagai panglima perang atau polisi negeri yang bertugas menjaga ketertiban masyarakat dan menjaga keamanan negeri. Semua pejabat pemerintahan negeri tersebut di atas bergabung kedalam suatu dewan negeri yang bernama "Badan Saniri Negeri".

\section{METODE PENELITIAN}

Penelitian deskriptif kualitatif merupakan salah satu dari jenis penelitian yang termasuk dalam jenis penelitian kualitatif. Adapun tujuan dari penelitian ini adalah untuk mengungkapkan kejadian atau fakta, keadaan, fenomena, variabel dan keadaan yang terjadi saat penelitian berlangsung dengan menyungguhkan apa yang sebenarnya terjadi. Penelitian ini menafsirkan dan menguraikan data yang bersangkutan dengan situasi yang sedang terjadi, sikap serta pandangan yang terjadi di dalam suatu masyarakat, pertentangan antara dua keadaan atau lebih, hubungan antar variable yang timbul, perbedaan antar fakta yang ada serta pengaruhnya terhadap suatu kondisi, dan sebagainya.

Menurut Nazir (1988), metode deskriptif merupakan suatu metode dalam meneliti status sekelompok manusia, suatu objek, suatu set kondisi, suatu sistem pemikiran ataupun suatu kelas peristiwa pada masa sekarang. Tujuan dari penelitian deskriptif ini adalah untuk membuat deskripsi, gambaran, atau lukisan secara sistematis, faktual dan akurat mengenai fakta-fakta, sifat-sifat serta hubungan antarfenomena yang diselidiki.

\section{HASIL DAN PEMBAHASAN}

\section{Sejarah Singkat dan Asal Usul Negeri Murnaten}

Pada zaman dahulu disuatu tempat bernama Sobainlatale hidup sejumlah orang atau penduduk, tetapi mereka tidak berkembang sehingga mereka pindah lagi ke Seiyalatale. Di tempat tersebut mereka hidup lama dari generasi ke generasi dan berkembang sehingga mereka tidak lagi hidup berdampingan dengan damai, dan pada akhirnya timbul peperangan diantara mereka sehingga sebagian dari mereka pindah ke tempat yang bernama Ulate Babelu. Di Ulate Babelu, terjadi permasalahan antara penduduk sehingga sebagian orang yang merupakan orang Murnaten berpindah lagi ke suatu tempat yang bernama Batu Layana kemudian berpindah lagi ke Ramali Rokone (penghuni besar) karena di Batu Layana tidak luas untuk menjadikan sebuah pemukiman.

Di Ramali Rokone (penghuni besar) terjadi sebuah peristiwa dimana ada seorang nenek yang bernama Uwene turun mengambil air tetapi ternyata air sudah kering karena ada seekor Morea (Belut) melintang/menghalangi air itu. Kemudian nenek tersebut berteriak sehingga semua orang/penduduk keluar dengan alat, mereka mengira ada musuh yang menyerang, padahal bukan musuh tetapi seekor morea, kemudian mereka membunuhnya dan membagikan kepada semua penduduk dan yang mendapat kepala morea itu adalah nenek yang menemukannya. Selanjutnya mereka semua pulang kerumah untuk memasak morea tersebut dan hari sudah malam. Kemudian kepala morea yang dimasak oleh nenek itu tidak pernah matang/masak, akhirnya ia memanggil penduduk sekitar untuk memberitahukan hal itu kepada mereka, namun mereka mengatakan bahwa mereka sudah selesai makan bagian mereka, tetapi nenek itu menyatakan bahwa kepala morea itu tidak masak namun kepala morea itu berbicara bahwa "Kesa-kesa ramali (tamasu), Robi-robi ramali (longsoran)" dan akhirnya pada malam itu terjadi bencana longsor sehingga mengakibatkan banyak penduduk menjadi korban.

Dari beberapa keluarga yang tertinggal atau selamat mereka lalu pindah ke suatu tempat yang bernama Belukaya atau Ulama Kalate, selanjutnya mereka pindah lagi dan bermukim di Hataule Tutini artinya Tuer Bitanggur. Kemudian pada tahun 1845 mereka membentuk pemerintahan terdiri dari Raja, Kepala Soa, Saniri, Marinyo dan Kewang yang di pimpin oleh Soya Ulate sebagai Raja. Soa yang terbentuk adalah sebanyak 5 ( lima ) Soa yaitu : 
1. Soa Nurue.

2. Soa Latue.

3. Soa Touwe / Maketake.

4. Soa Ulate.

5. Soa Elly Kakay.

Kemudian perang Rumah Soa pada tahun 1845, pemimpin Soya di tangkap mengakibatkan masyarakat terpencar ke berbagai tempat. Tahun 1905 masyarakat Murnaten turun kepantai di pimpin oleh seorang yang bernama Masai Petrus Ulate, cucu dari Raja Soya, dan mereka menetap di Negeri Murnaten sampai saat ini.

\section{Konsistensi Dalam Menerapkan Ketentuan Adat Dalam Pemilihan}

Menurut Cambridge Dictionary mengartikan konsisten sebagai sesuatu yang tidak berubah atau selalu bertindak atau terjadi secara sama, terutama dalam hal positif. Selain itu Cambridge Dictionary juga mendefinisikan konsisten sebagai suatu kesepakatan, atau memiliki kesamaan dengan hal lainnya, atau dapat diartikan memiliki prinsip yang sama dengan hal lainnya. Sumber lain juga mendefinisikan konsisten sebagai suatu kegiatan yang dilakukan secara terus menerus dan benar tanpa keluar dari jalur atau batasan yang telah ditentukan. Selain itu, ada pula yang mendefinisikan konsisten sebagai salah satu sikap manusia yang memegang teguh suatu prinsip atau pendirian.

Ketika ketentuan adat itu tidak di laksanakan maka akan menimbulkan konflik sektoral dalam masyarakat karena semua akan mau untuk menjadi Raja Negeri, Sehingga dengan demikian akan menimbulakn pertikaian antara masyarakat. untuk itu menurut kami hukum adat atau ketentuan adat harus di lestarikan dan laksanakan secara konsisten dalam pemilihan Raja Negeri, karena dengan dengan demikian akan terpelihara rasa persaudaraan anatara masyarakat di Negeri Murnaten dalam pemilihan Raja Negeri Murnate (Wawancara, Ateng Ulate, 2019). Dalam pemilihan Raja Negeri berdasarkan adat di masyarkat negeri Murnaten bahwa, Raja Negeri di pilih berdasarkan sejara adat masyarakat negeri Murnaten dalam artinya berdasarkan mataruma parentah yang sudah ditetapkan oleh para leluhur pada jaman sejarah mereka, namun kesemuannya itu harus melalui demokrasi dalam matarumah parentah siapa yang berhak dan siapa yang layak untuk di pilih sebagai Raja Negeri, dengan melibatkan unsurunsur adat lainnya seperti ketua adat, semua soa-soa yang ada di negeri Murnaten. Sehingga dengan demikian akan menjadi sebuah kesepakatan dalam musyawarah adat untuk pemilihan Raja Negeri.(Wawancara, Lodik Touwe, 2019)

\section{Dukungan Masyarakat Terhadap Ketentuan Adat Yang Berlaku}

Dukungan adalah pemberian dorongan, motivasi atau semangat serta nasehat kepada orang lain yang sedang di dalam situasi membuat keputusan. (Chaplin : 2006). Pengertian dukungan adalah segala bentuk informasi verbal ataupun non verbal yang bersifat saran, bantuan yang nyata maupun tingkah laku diberikan oleh sekelompok orang yang dekat dan akrab dengan subjek di dalam lingkungan sosialnya. Pengertian informasi verbal adalah pesan atau informasi dalam bentuk kata-kata yang disampaikan secara lisan maupun tulisan.

Adapun dukungan dari masyarakat negeri murnaten terhadap ketentuan adat yang sudah berlaku kina telah terbagi. Karena kepentingan politik yang mana sebagian masyarakat mendukung pemilihan raja berdasarkan ketentuan adat sedangkan sebagian dari masyarakat negeri murnaten ini menginginkan pemilihan raja secara demokrasi. Demi menjaga kelestarian budaya atau kebiasaan leluhur kami maka, Kami sebagai tokoh adat menginginkan dan terus mendukung pemilihan raja ini tetap berdasarkan ketentuan adat yang sudah di bentuk atau 
disepakati dari zaman leluhur. Agar budaya atau kebiasaan adat ini tidak hilang dan tetap terus di terapkan atau dikembangkan dari generasi ke generasi.(Wawancara, Simon Elly,2019)

Ketaatan masyarakat terhadap aturan (hukum) mencerminkan kesadaran hukum yang dimiliki oleh masyarakat.Semakin tinggi kesadaran masyarakat maka semakin rendah tingkat pelanggaran hukumnya. Sebuah aturan hukum akan ditaati dan dipatuhi oleh masyarakat apabila aturan tersebut memberikan jaminan bagi mereka akan hak dan kewajiban secara proporsional. Ketika seseorang merasakan suatu aturan yang melingkupinya memberikan kenyamanan maka individu tersebut akan tunduk dan patuh pada aturan hukum tersebut. Dalam kenyataannya dalam masyarakat hidup aturan yang tidak tertulis, yang lebih dikenal dengan hukum adat. Walaupun aturan-aturan tersebut tidak tertulis tetapi masyarakat(adat) mematuhi aturan tersebut. Berbicara mengenai ketaatan masyarakat negeri murnaten terhadap seluruh keputusan adat dalam pemilihan raja tidak lagi sama seperti dahulu kala tetapi kina telah berubah, yang mana sebagian dari masyarakat negeri murnaten tidak lagi mengikuti aturan adat tentang pemilihan raja yang telah disepakati bersama. Karena adanya kepentingan poitik yang bersifat menghasut sebagian dari masyarakat murnaten untuk tidak lagi mengikuti aturan adat tersebut. (Wawancara, Kace Ulate, 2019). Nama Murnaten berasal dari kata Sonatene yang artinya Bunga Gadihu, nama Pelabuhan adalah Tambirone berasal dari kata Paitlone artinya tempat siri pinang, Negeri Murnaten termasuk Inama Tihumeten berdasarkan sidang Adat Eti Batai. Struktur masyarakat adat yang hidup di Negeri Murnaten yang ada saat ini dapat dikatagorikan dalam: Bangsa Raja, Bangsa Kepala Soa, Bangsa Kewang, Kapitan dan Anak-anak Negeri Masyarakat dikelompokkan dalam Mata Rumah (Rumah Tua) dan Masyarakat Soa. Baik Negeri, Soa Mata Rumah, Rumah Adat, dan Tempat-tempat Keramat mempunyai nama adat untuk gelar upacara kehormatan adat (Upu/mata) yang sebagai berikut:

\section{Struktur Adat ( Batu Lessi )}

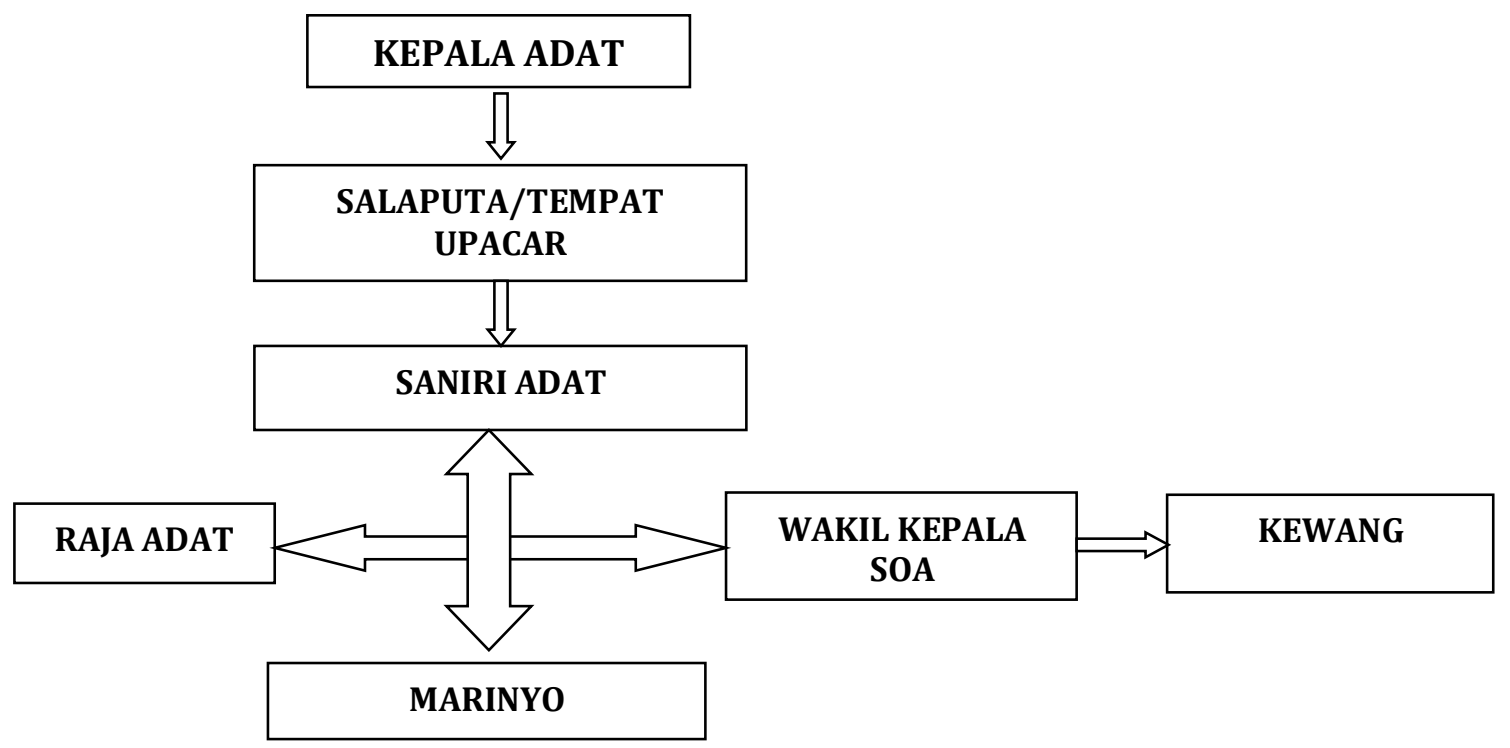




\section{Sejarah Negeri Murnaten Sejak Awal Turun Dari Nunusaku}

Negeri ini awalnya belum mempunyai nama karena pada saat itu belum ada satu negeri yang turun ke pesisir sebelum ada pemerintah dari Upu Latu yang di sebut sebagai Raja. Namun karena penduduk semakin bertambah banyak maka semua negeri harus berkumpul melalui Perintah Upu Latu untuk di bicarakan tentang pembagian hak-hak negeri yang di dalamnya ada beberapa Soa atau Marga yang terdiri dari beberapa Teon Mata Rumah, seperti marga Nurue , marga Latue, marga Touwe, marga Seay, marga Elly dan marga Ulate.

Dari hasil keputusannya masing-masing mencari tempat sesuai arah dan petunjuk dari perintah dan harus saling mengakui antara satu sama lain berdasarkan musyawara bersama. Mereka menerima tandah yang di dapat dari Upu Latu yaitu sepotong jaga gatal babi yang bisa di tanam sebagai pilar atau nama negeri. Sekalipun perjalanan begitu jauh tetapi belum bisa untuk di tanam kalau belum di pastikan bahwa negeri itu bisa menetap.

Akhirnya nama Negeri Murnaten ada karena sejarah gatal babi, kalau di sebut dengan bahasa Alune (Sana Tenene), kalau di ucap dengan kesempurnaan bahasa Indonesia Murnaten. Negeri ini memiliki lima Soa yang mempunyai arti bagi semua orang untuk bisa mempertahankan jati diri sebagai anak-anak adat karena masih ada Teonnya atau Mata Rumah.

1). Marga Nurue atau Nurule,Teonnya

(a). Latu Luma Pui, yang artinya Tuan Rumah

(b). Luma Elake

(c). Luma Pasalwey

(d). Luma Tibu Inai (kandungan ibu) dan

(e). Telue Elusa).

Nurue ini di dapat dari satu benda alam yaitu Nibon Tuni, yang di gunakan untuk tongkat Marga karena di terima melalui suatu bencana yaitu Guntur dan kilat yang terjadi pada rapat pertama di kota lima saat pembagian hak-hak negeri termasuk marga-marga sehingga tumbang satu jenis tumbuhan tersebut. Akhirnya marga Nurue itu ada karena cahaya. Ada juga Nurue Tenine, Nurue Anilekwe yang mempunyai tugas untuk mengontrol dan memberi informasi, dll.

2). Marga Latue "ada Latue Tenine, Latue Lemosol, Latue Batu Muli teonnya

(a). Latu Sipatway dan

(b). Alamana.

3). Marga Touwe, Touwe Batai, Touwe Luma Muene teonnya

(a). Luma Uwene Ankota,

4). Marga Seay Ela Bubui tidak ada teonnya,

5). Marga Elly, Elly Luma Pui, Elly Tenine, Luma Latu tidak ada teonnya.

6). Marga Ulate, tidak mempunyai Teon karena asal mereka orang yang di tawan pada zaman perang di salah satu gunung yaitu gunung Nebo. Tetapi ada satu keluarga yang kawin dengan seorang perempuan dari marga Nurue / Nurule Mata Rumah Kapitan, sehingga dia di beri kepercayaan untuk menjadi Raja pada zaman VOC sampai sekarang.

Melalui sumpah adat sehingga tidak bisa di ganggu gugat oleh siapapun, bisa di ganti apabila mata rumahnya sudah puna. Marga-marga ini mempunyai arti Teon seperti yang sudah di artikan oleh Marga Nurue atau Nurule. Kemudian masalah budaya, kehidupan acara lain. Dan kalau bekerja masih bersifat gotong-royong, begitupun acara perkawinan adat waktu pembayaran harta semua orang di bebani untuk membayar bersama, termasuk keluarga yang 
tidak mampuh untuk meningkatkan pendidikan ke perguruan tinggi, semua juga di bebani untuk tanggung bersama. Hal ini sudah menjadi suatu budaya yang di bangun sejak purbah kala. Demikian sejarah ini, kalau ada yang masih kurang mohon di maafkan, sekian dan terima kasih.

\section{Struktur Pemerintahan Negeri Murnaten}

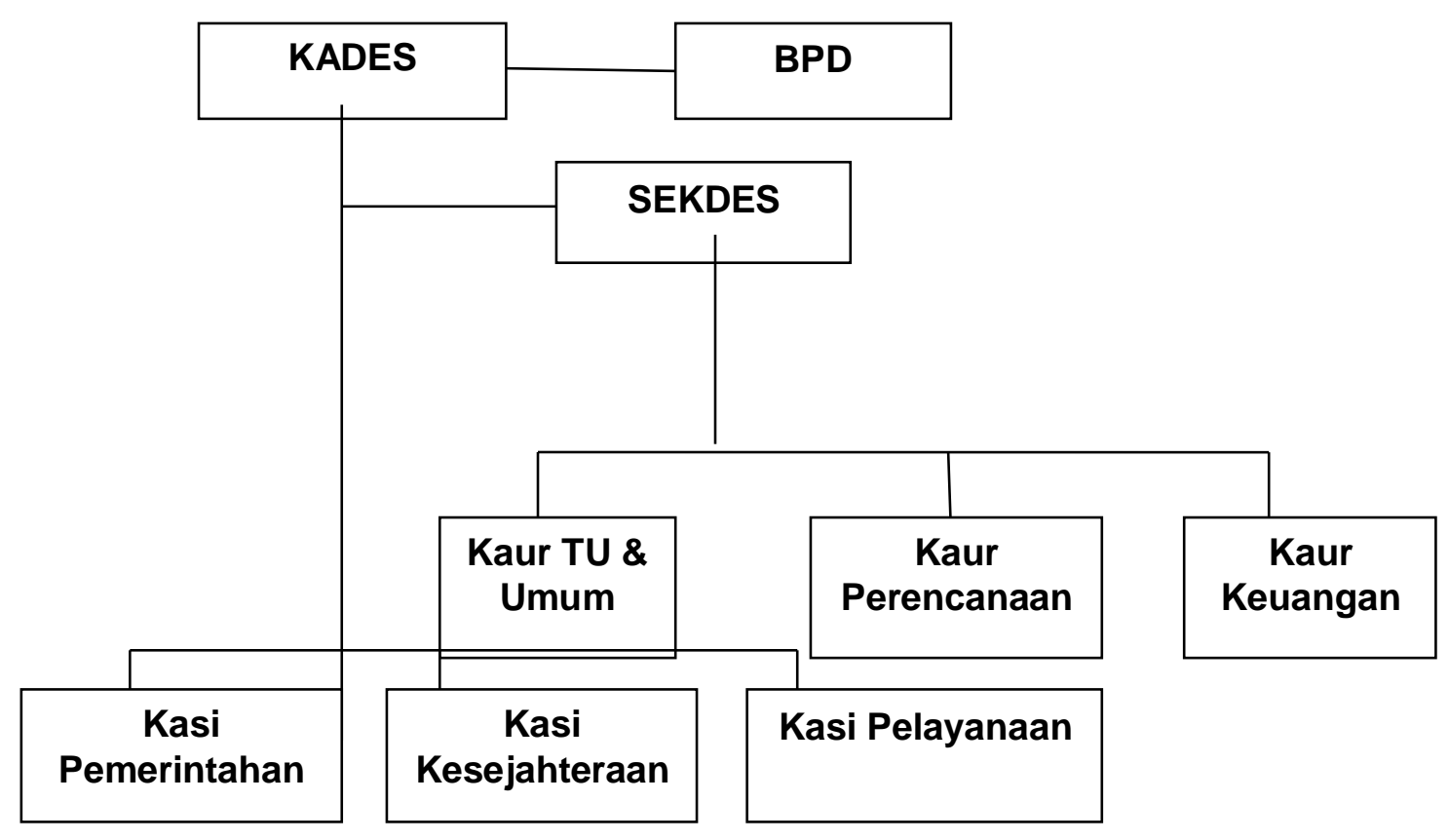

\section{Awal Proses Pemelihan Raja Serta Lahirnya Mata Rumah Parentah dan Perangkat Adat Negeri Murnaten.}

Negeri Rumah Soal awalnya di kenal sebagai negeri yang menampung semua soa yang ada di Maluku sebelum terpisah dengan negeri-negeri lain, karena pada waktu itu juga rumah soal sebagai pusat pemerintahan Nunusaku untuk mengatur semua strategis menyangkut dengan hak-hak wilayah kekuasan Nunusaku yang sudah diatur sejak awal.

Namun karena penduduk semakin bertambah banyak, maka tempat yang mereka huni tidak nyaman maka salah satu dari keluarga yang memimpin negeri tersebut menyarankan bawah negeri rumah soal turun ke pesisir supaya bisa membatasi negeri lain untuk tidak boleh masuk dengan berbagai politik dan menghancurkan bangsa Alifuru dan bangsa Wemale. Tetapi Upu Latu Rumah Soal tidak mau untuk mengikuti tawaran saudaranya itu, beliau tetap dengan pendiriannya, akhirnya saudaranya itu mulai berpikir untuk memecahkan pemerintahan Rumah Soal dengan cara membawa lari benda-benda kerajaan seperti gong, tahuri, dan tipa, bermaksud supaya tidak ada tanda berbunyi apapun untuk memanggil orang-orang di sekitar negeri itu untuk datang dan berkumpul di suatu tempat yang sudah menjadi tempat mereka berkumpul.

Sesudah mengambil barang-barang tersebut, maka barang-barang itu di pindahkan ke salah satu tempat yang bernama batu tanaya, kemudian dipindahkan lagi ke Ramali. Dari Ramali berpindah lagi ke Batu Lessi, disitulah negeri Murnaten mulai berdiri sendiri, mereka memulai mengatur pemerintahan sekaligus membuat struktur Pemerintahan Negeri, karena beberapa 
,marga sudah bergabung untuk menerima jabatan yang akan di berikan kepada masing-masing marga sesuai dengan tupksi mereka berdasarkan musyawara yang mendepankan asas demoraksi.

1. Marga Nurue sebagai marga pertama karena marga inilah yang menjadi marga parentah di Rumah Soal berdasarkan Mata Rumah yang menentukan sebagai Latu Luma Pui yang artinya Tuan Rumah Raja.

2. Marga Latue sebagai wakil pemerintah yang dikenal sebagai Latu Sipatwai yang artinya mata rumah yang bisa juga untuk mengatur apabila dia mendapat kepercayaan, tetapi ada batas-batas tertentu yang tidak boleh di langgar sesuai dengan aturan yang sudah di buat oleh marga Nurue sebagai Tuan Rumah Raja.

3. Latu Alamana sebagai juru bicara atau seorang protocol.

4. Marga Touwe, marga ini berperan sebagai petugas upacara pada saat upacara adat, rapat-rapat, tugasnya adalah mempersiapkan ruangan upacara adat atau ruang rapat, setelah itu beberpa marga atau mata rumah meyesuaikan untuk menerima jabatan kepala soa dan marinyo, termasuk kewang dll.

\section{Kesepakatan/Perjanjian Bersama Terhadap Pemberlakuan Ketentuan Adat}

Suatu perjanjian adalah persetujuan (tertulis atau dengan lisan) yang dibuat oleh dua pihak atau lebih yang masing-masing berjanji kan mentaati apa yang tersebut dalam persetujuan itu. Dari peristiwa tersebut terbitlah suatu hubungan hukum antara kedua belah pihak tadi yang dinamakan perikatan. Jadi perjanjian adalah sumber dari perikatan di samping sumber lain yaitu undang-undang. Perjanjian peristiwa nyata dan dapat dilihat wujudnya karena dalam suatu perjanjian kita dapat melihat atau mendengar janji-janji yang diucapkan oleh parah pihak yang mengadakan persetujuan atau dapat pula membacanya dalam kalimat yang berisi kata-kata janji yang telah dibuat dan disetujui oleh parah pihak dalam suatu perjanjian tertulis. Dalam Kamus Besar Bahasa Indonesia Perjanjian adalah persetujuan tertulis atau dengan lisan yang dibuat oleh dua pihak atau lebih, masing-masing bersepakat akan mentaati apa yang tersebut dalam persetujuan itu. Berdasarkan hasil wawancara dengan Bapak Ekel Nurue selaku Ketua BPD beliau menyampaikan bahwa :

Adapun kesepakatan bersama antara pemerintah negeri murnaten dengan seluruh masyarakat negeri murnaten bahwa kesepakatan bersama terhadap ketentuan adat dalam pemilihan raja sudah di sepakati dari zaman leluhur yang dimana dalam proses atau pengangkatan raja harus dari mata rumah parentah (Nurue) tidak boleh dari mata rumah lain, ini yang telah di sepakati bersama.

Namun, berdasarkan masalah pemilihan raja yang terjadi sekarang yang dimana pihak tokoh adat menginginkan pemilihan raja secara adat untuk mempertahankan adat atau kebiasaan dari leluhur terdahulu tidak sepemikiran dengan para pihak pemuda murnaten yang menginginkan pemilihan raja secara demokratis, sehingga masalah ini belum ada kesepakatan bersama antara pemerintah negeri murnaten dengan masyarakat murnaten

Berikut ini akan disajikan periodisasi sejarah pemerintahan raja-raja negeri Murnaten.

1. Alm. Soya Ulate

2. Alm. Palia Ulate

3. Alm. Patia Ulate

4. Alm. Masai Petrus Ulate

5. Alm. Eduard Ulate

6. Alm. Hendrek Nurue

7. Alm. Jermias Latue, Tahun $1968 \mathrm{~s} / \mathrm{d} 1994$

8. J. A. Ulate, Tahun $2007 \mathrm{~s} / \mathrm{d} 2019$. 
Berdasarkan hasil penelitian, penulis dapat menyampaikan serta menjelaskan peran serta fungsi mata rumah parentah sebagai barikut. Peran serta fungsi mata rumah parentah dalam negeri adat adalah sebagai kepala adat yang berarti mata rumah parentah merupakan kepala adat yang mengatur segalah sesuatu yang menyangkut upacara adat maupun permasalahanpermasalahan yang terjadi dalam negeri dan hal-hal penting lainnya dalam masyarakat. Hal yang sama disampaikan oleh kepala soa lainnya namun lebih ditegaskan bahwa mata rumah parentah merupakan bapak dalam sebuah negeri yang memiliki hak untuk memerintakan atau menjadi Raja dan mengatur pemerintahan dan memutuskan segala sesusatu dalam negeri bersama dengan kepala soa dan saniri negeri. Jadi dapat disimpulkan bahwa peran dan fungsi mata rumah parentah memilikih hak sebagai kepala adat atau, yang secara jelas digambarkan memiliki hak sebagai raja dan mempunyai hak untuk memimpin negeri, dalam hal negeri Murnaten berdasarkan asas Adat dan Demokrasi.

\section{KESIMPULAN}

Adat dalam kehidupan demokrasi desa (studi kasus pada pemilihan Raja Negeri Murnaten Kecamatan Taniwel Kabupaten Seram Bagian Barat Provinsi Maluku). Demokrasi masyarakat adat negeri Murnaten berakar dari pancasila sila ke-4 yakni demokrasi permusyawaratan. Di dalam demokrasi masyarakat adat negeri Murnaten selalu mengutamakan adat dalam demokrasi terkhusus dalam pemilihan Raja Negeri karena bagi mereka adat dan demokrasi dalam kehidupan masyarakat negeri Murnaten dapat memenuhi nilai-nilai mendasar dari demokrasi tersebut, yakni nilai kesetaraan, keadilan, nilai gotong royong, nilai toleransi, nilai religius dan tidak kalah penting adalah kejujuran. Dalam proses pemilihan Raja Negeri Murnaten pada masyarakat hukum adat negeri Murnaten, dapat di temukan semua nilai-nilai mendasar demokrasi yang ada dalam sistem adat masyarakat sesuai dengan UUD 1945 dan Pancasila yang mana sebagai dasar negara Indonesia. Implementasi dari nilai-nilai demokrasi tersebut telah ada secara turun temurun sejak pada leluhur mereka sampai saat ini dan akan terus dilaksanakan sampai kapanpun, baik itu pada proses pemilihan Raja Negeri maupun dalam kehidupan mereka sehari-hari.

\section{UCAPAN TERIMA KASIH}

Kami ucapkan terima kasih kepada Prodi Ilmu Pemerintahan, Fakultas Ilmu Sosial dan Ilmu Politik, Universitas Pattimura yang telah memberikan motivasi dan bimbingan sehingga hasil penelitian bisa selesai dan bisa di publikasikan pada jurnal nasional.

\section{REFERENSI}

Pip Jones. 2010. Pengantar Teori-Teori Sosial: Dari Teori Fungsionalisme Hingga PostModernisme. Jakarta: Yayasan Obor Indonesia.

Laksanto Utomo, Hukum Adat, Jakarta: RajaGrafindo Persada, 2016.

Khairuddin Tahmid, Demokrasi dan Otonomi Penyelenggaraan Pemerintahan Desa, Bandar Lampung: Seksi penerbitan Fakultas Syari'ah IAIN Raden Intan Lampung, 2004.

Inu Kencana Syafiie, Sistem Pemerintahan Indonesia, Jakarta: Rineka Cipta, 2002.

Hilman Hadikusuma, Hukum Ketatanegaraan Adat, Jakarta: Alumni Bandung, 1981.

Hilman Hadikusuma, Pengantar Ilmu Hukum Adat Indonesia, Edisi Revisi, Bandung: Mandar Maju, 2014.

Firman Sujadi, dkk, Pedoman Umum Penyelenggaraan Pemerintahan Desa landasan Hukum dan Kelembagaan Pemerintahan Desa, Jakarta: Bee Media Pustaka, 2016. 
Departemen Pendidikan Nasional, Kamus Besar Bahasa Indonesia Pusat Bahasa, Edisi Keempat, Jakarta: Gramedia Pustaka Utama, 2011

Michael Laws. 2009. Conflict: Mencabut Akar\& Menyelesaikan Konflik. Yogyakarta: Andi

Pattikayhattu, J. A. Sejarah Negeri Dan Desa Di Kota Ambon. Dinas Pariwisata Kebudayaan Pemuda Dan Olahraga Kota Ambon 2009.

Pattikayhatu, J.A (2008). Negeri-Negeri Di Jazirah Leitimor Pulau Ambon. Yogyakarta; Citra Adi Parama.

Wirawan, I. B. 2013. Teori-Teori Sosial Dalam Tiga Paradigma: Fakta Sosial, Defenisi Sosial, Dan Perilaku Sosial. Jakarta: Kencana.

Sugiyono, 2012, Metode Penelitian Kuantitatif kualitatif dan R\&D. Bandung Alfabeta Bandung.

R. Soerojo Wignojodipoero, Kedudukan Serta Perkembangan Hukum Adat Setelah Kemerdekaan, Jakarta: PT Gunung Agung, 1983

Sabaruddin sa, Sai Bumi Ruwa Jurai Lampung Pemerintahan-Adat Istiadat-SastraBahasa, Jakarta: Buletin Way Lima Manjau

Taliziduhu Ndraha, Dimensi-Dimensi Pemerintahan Desa, Jakarta: Bumi Aksara, 1991.

Kristiadi, Jean. 2006. Pemilihan Umum dan Perilaku Pemilih di Indonesia. Prisma. Jakarta.

Dwipayana, AAGN Ari dan Sutoro Eko. 2003. Membangun Good Governance Di Desa. IRE Press. Yogyakarta

Djaenuri, Aries dkk. 2003. Sistem Pemerintahan Desa. Pusat Penerbitan Universitas Lampung. Bandar Lampung

Dahl, Robert A. 1985. Dilema Demokrasi Pluralis Antara Otonomi Dan Kontrol. Rajawali Pers. Jakarta

Wance, M., Muhtar, M., \& Kaliky, P. I. (2020). PKM Penyelenggaraan Pemerintahan Dalam Perencanaan Pembangunan Negeri Hila Kabupaten Maluku Tengah. CARADDE: Jurnal Pengabdian Kepada Masyarakat, 2(2), 229-338.

Zuhraini, Kesatuan Masyarakat Hukum Adat Dalam Dinamika Politik Hukum Indonesia, Bandar Lampung: Harakindo publishing, 2014.

Zuhraini, Hukum Pemerintahan Desa, Bandar Lampung: Pusat Penelitian dan Penerbitan LP2M Institut Agama Islam Negeri Raden Intan Lampung, 2016

\section{Peraturan Perundang}

Peraturan Daerah Nomor 1 Tahun 2006 tentang Negeri

Peraturan Daerah Nomor 3 Tahun 2006 tentang Tata cara Pencalonan, Pemilihan dan

Pelantikan Kepala Pemerintahan Negeri. 